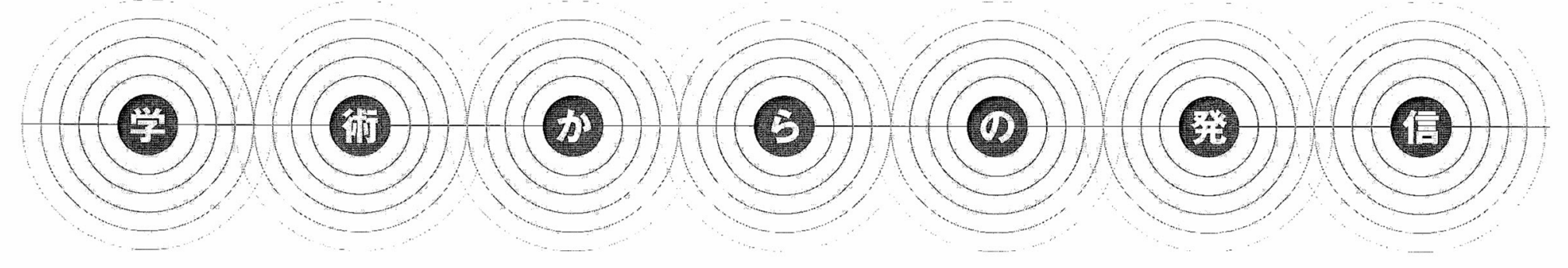

\title{
これが人の夢、人の望み、人の業!! 一ガンダムSEEDに見るバイオテクノロジーと人類の将来一
}

私はアナーキズム研究者の端くれで ある。そのような者がなぜ内閣府に属 する日本学術会議の連携会員に採用さ れ、しかも爷の広報誌に寄稿する羽目 に陥つたのか。耐气難き矛盾である。 あたかもコーディネーターなのにナチ エラルのために戦わざるをえなくなつ

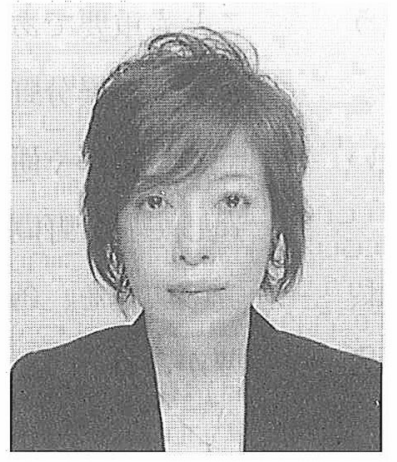

住吉雅美
態に、人文科学とくに生命倫理や法 哲学などの分野はどう対応している か。

中央集権的な決定に服しての技術 利用によって強制的・組織的に「国 民改良」を進めるといら仕方には、 20 世紀前半に優生学とファシズムと たキラ・ヤマトである。しかし愚痴ばかり言っても いられないので、さっさと原稿を書いてアキバに行 こう。私の目下の最大の関心事はガンダムなのだが、 「学術からの発信」を書くよう依頼されたので、強引 にガンダムがらみの生命倫理の問題を取り上げてみ た。

\section{「リベラル優生主義」の㭙代？}

体外受精の技術によって、いまや着床前骖断で生 命の選別（重篤な遺伝性疾患をもつ子を生まないこ と）がなされ、かつ肧選択の実現とヒトゲノム解析 の進行は、単因子遺伝病の発生阻止や積極的肧選択、 再生医療、ゲノム改造を可能にしつつある。つまり 科学技術の分野では、クローン技術や遺伝子介入に よってある程度「望ましい子」を人為的に作りうる 段階を迎えようとしているのである。このような事
の結託がもたらした悲劇のトラウマゆえに概ね否定 的な意見が強い。炎れへの反省を踏まえながらも現 代では、個人の自由や幸福追求権を重視するリベラ ルな視点から、個人の「生殖の自由」のみに基づくと いう条件下に技術使用を肯定する傾向が顕著であ る。この傾向についての詳細と分析は、優れた近著 である桜井徹『リべラル優生主義と正義』（ナカニシ ヤ出版、2007年) に譲るが、そこでも紹介されてい る象徴的な一例として、1998年3月にカリフォルニ ア大学ロスアンゼルス校にて開がれた「ヒ生殖細 胞系列を設計する」シンポジウムでの主要論調、即 ち遺伝子工学は人間にとって合理的に自己進化を達 成するための手段であり、最適な仕方で用いられれ ばよい、という主張があげられる。また、生命倫理 に関心を持つ人文科学のリベラルな研究者たちの議 論を概観すると、技術利用を人類進化の手段として 
積極的に肯定するもの $(\mathrm{G} ・$ ストック)、人間の苦を 除去するための生命科学の利用を一貫して認めるも の $(\mathrm{L} \cdot \mathrm{M}$ ・シルヴァー)、消極的ではあるが「改 良」にでなく「治療」に限定しての技術利用であれ ばよいとするもの（F・フクヤマ）等がみられ、積 極性の濃淡こ号あれ、基調的にはほぼ人間への技術

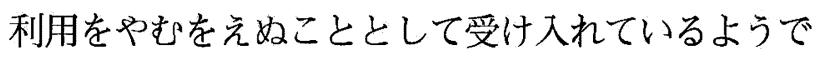
ある。法哲学・法理学のリベラルな陣営からも、た とえば倫理的個人主義を前提として「人類を長命に したりより優れたものにするという野心は悪くな い」(R・ドゥオーキン) という主張、さらにはリバ タリアニズム (自由尊重主義) からは、子作りに関 しては親の自由な選択に委ね、夫婦独自の細かい注 文に応じるシステム即ち「遺伝子スーパーマーケッ 卜」の提案がなされている(R・ノージック)。

世界的な自由化の趨勢、さらには国家間の開発競 争に強力に後押しされ、遺伝子介入が広く利用され

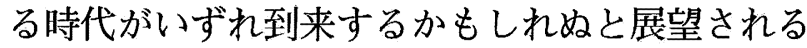
が、仮に只うなった場合、いかなることが起こるだ ろうか。まず単純に技術がもたらしうる利点として 考えられることは、生まれてくる子の重篤な遺伝病、 また成人病、ガンなどの遺伝的因子が改良されるこ と、ウィルス等への抵抗力を高めるための遺伝子介 入がなされること、遺伝子工学によって人間の五感 や精神的能力の改良が可能になること、等である。 しかも自由主義、它ればかりか倫理に関する合理的 推論を貫けば遺伝子介入への反駁は直観主義による 以外には困難であり、上述のメリットを生み出しう る研究它のものを禁止する決定的論拠も示されてい ないのが現状である。

\section{コーディネイターVS.ナチュラル}

もちろんその一方で㝥念されることもある。リべ ラルな論者によっても、人類の階層化、即ちジー ン・リッチ階級（恵まれた遺伝子、健康な身体、安 定した精神を備えた富裕階級) とナチュラル階級 （遺伝子の改良を受けられないため心身共に弱い䝷 困階級) とが生じ、対立が起こる可能性が指摘され ている。この可能性についてはすでに人口に膾多し、 SF映画化もされているが、私が思うに、この対立 の一層の先鋭化が宇宙規模で深刻な戦争を生み出す 状況、ならびにそこで生じうる倫理問題を劇的に描 いている作品は、日本のモビルスーツアニメ『機動 戦士ガンダムSEED』(矢立肇・富野由悠季原作、以 下SEEDと略称)である。遺伝子介入がもたらす人 類格差社会の行く末にいかなる倫理問題が起こりう るか、この作品から垣間見てみよう。

《遺伝病対策として開発された技術の発展に基づ き、C.E. (コズミック・イラ) 30 年代に遺伝子改変 ブームが起こった。この時期に、親の自由選択によ って受精卵の段階で遺伝子操作を受け生まれた人間 をコーディネーターと呼ぶ。吕れはヒトのもつ潜在 的能力を最大限引き出した、作られた超人であり、 知力体力共に優れ、病にかから始螨な肉体をもっ ている。彼らはナチュラル（自然姡娠・分婏によっ て生まれた人々)より優れた能力をもつことから自 ずと優位に立ち、結果としてナチュラルの恠妬を買 い迫害されたため、宇宙に自らの国家「プラント」 を作り移住した。彼らはそこで高い技術力と宇宙環 境の特性を活かして工業生産やエネルギー生産を行 い、地球からの独立の機運を高めていった。一方、 
地球上ではブルーコスモスというロビィ団体が先頭 に立ち、コーディネーターへの敵意が強められてい った。ブルーコスモスは「自然」概念を利用し「青 き清净なる世界のために」を合言葉に遺伝子改良を 阻止せんとし（まさに直観主義の権化であうう）、 コーディネーターを「自然の搷理に背いた許されざ る存在」と断罪した。C.E. 70年、ついに地球連合軍 が農業プラントに核爆弾を撃ち込み、20万人以上の コーディネーターを殺翏する。これを契機に、ナチ ユラルの地球連合軍とコーディネーターのプラン ト=ザフト軍との全面戦争に突入するのである。

SEEDではリベラルな積極的優生主義の果てに人 類がコーディネーターとナチュラルとに分断化さ れ、しかも両者の間に圧倒的な能力的格差が生じた が䘛の相互不信の拡大、学の結果としての全面戦 争の悲劇が生々しく描かれている。クローン技術に よって生をうけたが染色体のテロメア短縮化のため 老化が早く進行する症状に苦しむザフトのエリート 軍人クルーゼは、遺伝子改変技術の普及をこう呪詛 する、「受精卵の段階で、人為的な遺伝子操作を受 けて生まれた者…あらゆる容姿、あらゆる才能が、 すべて金次第で自分（の子供）のものになる。まる でアクセサリのように。人は、何を手に入れたの だ!? その手に!その夢の果てに!・よりよきものを と人は望んだ。そして只の結果何を生み出した? 新 たな偏見、新たな差別、新たな対立一そして今の、 いつ果てるともしれないこの争いだ。旮してねたみ、 増み、殺し合うのさ!それがヒトの本質なのか？」。 生殖細胞系列への遺伝子工学応用が格差を増大させ る可能性は、近年研究者も指摘しているところであ る。先れは、富裕層の子のみが生得能力の限界を超
元、改良されたまたは新たな能力を獲得しうる結果 「二重に強い競争者」となり光、よって富裕層と䝷 困層との格差が一層拡大寸るというかたちで生じ元 よう。とはいえこの格差問題も（とりわ计資本主義 下に抏いて）長期的展望でみれば、遺伝子操作技術 の改良と低価格化の進行によって、所得に関わりな く希望者は誰でも受けられるという段階に至れば、 軽減されるかもしれない。

\section{変容する「人閒の本性」}

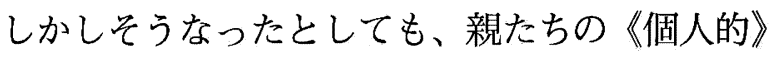
な「生殖の自由」に基づき遺伝子介入されて生をう けた人々の大量出現の行く末はゼうなるだううか。 しばしば指摘されるのが、医療遺伝子学は欠樎遺伝 子を排除の対象とすることによって「障碍」をもつ 人々への差別の眼差しを強め、そのような人々に 「不完全な人格」としての地位を与えてしまうので はないかという懸念である。だが、生殖細胞系列に 介入して遺伝病の可能性のある妊娠を避ける方法 は、出生前診断の結果次第で人工中絶することと違 い生まれうる障碍者の存在冚のものを否定するわ けではない。また、人々を《正常な機能》へと近ゔ けて社会生活の全領域に参加できる競争者とする 「ヘルス・ケア」というサービスにも、社会の生産 の総量を高めつつ「機会の平等」に近づこうとする 意味で重要な道德的価值があるということを軽視す べきではなからう(A・ブキャナン)。

起こりうるより興味深い問題は、「人間の本性」 なるものの変容可能性である。親は子の幸福を願つ て子の能力や気質（あげくには容姿までも）をコー デイネイトする。先の結果が親の思惑通りに実現す 
るかどうかはともかくも、概して親は、我が子が他 の子たちよりも可愛いと考えるから、我が子が自己 犠牲的で利他的な献身的人物に育つことを選ばない だうう。ということはデザインされて生まれる子の 多くは、体力知力いずれも高く、容姿端麗の上に性 格的には利已的で攻撃的、抜け目ないという意味で 賢く、他者への同情心が稀薄もしくは皆無という人 物である可能性がある。SEEDでは、コーディネー ターでザフト軍のエース・パイロットが、恋人を戦 闘で失って悲しむナチュラルの少女に対して「バッ カみてえ!なに泣いてんだよ。馬鹿で役立たずなナ チュラルのカレシでも死んだかァ?」と罵る。この、 いまだに《地球の重力に魂を引かれている愚かなナ チュラル》からみるとあまりに無神経な言動も、コ ーディネーターだけの世界では常識的な感情となっ ているかもしれない。ダーウィニズムそしてリべラ 儿優生主義者たちは、人間の諸属性なるものは自然 選択過程と歴史的偶然との関数であって変化を免れ ぬものであり、「人間の本性」とてその例外ではな いと考えている。人間の力の規模が変化すれば、そ れに応じて従来の悪も善へと転じるかもしれない、 とは、あるリべラル優生主義者の言葉である。

\section{クルーゼの呪詛、再び}

知力体力ともに高度で攻撃的な性格の人間たちが 「生殖の自由」によって自ずと増殖した社会。しか も彼らはいかなる病にも悩まされず、老化も防止で きる。先のような社会は非常に競争が激しく、かつ 攻撃的で、弱者への配慮という福祉国家的思想は駆 逐される可能性がある (G・ストック)。「人間の本 性」についての見解も変わるとすれば、それに基づ
けられてきた権利観、ひいては倫理や法律学の大原 則も変わるかもしれない。社会権という権利は消滅 するかもしれない。民主主義は最善であるという了 解も変わるかもしれない。知力体力共に卓越した者 が独裁的に政治を行うことこそ望ましいとされ、権 利は万人に平等に与えられるべきではないという思 想はもはやタブーではなくなるかもしれない。もち ろん、人がゲノムを操作する力をもつに至ったなら、 逆に遺伝子を支配して「人間の本性」を利已性を乗 り越えるかたちで作りかえることも可能ではない か、という楽観的な議論もある。しかし人類はその ような《善意》にはたして全幅の信頼を置きうるも のであろうか。 $\mathrm{T} \cdot$ ホッブズはいつの時代にも・い かにしても封じることのできない人間行動の原動力 として、競争と不信と虚栄心（vainglory）を挙げ ている。

再び前述のクルーゼの呪詛が我々の《進歩》の行 く末に立ちはだかるだろう。「よりよきものをと人 は望み、その結果、……新たな偏見、新たな差別、 新たな対立一そして今の、いつ果てるともしれな いこの争い。そしてねたみ、憎み、殺し合う。それ がヒトの本質、…古来からずっと変わらず背負って きた人間の宿業？」。この宿業を、「人間の本性」と は違ういかなるものによってのりこえうるのだろう か？爷れが人文科学に課された今後の試練なのでは ないか。

\section{PROFILE}

住吉雅美（すみよし まさみ）

日本学術会議連携会員、青山学院大学法学部教授 専門：法哲学 